\title{
IMPACT OF BUSINESS MODELS CANVAS LEARNING ON IMPROVING LEARNING ACHIEVEMENT AND ENTREPRENEURIAL INTENTION
}

\author{
Saidun Hutasuhut", Irwansyah, Agus Rahmadsyah, Reza Aditia \\ Universitas Negeri Medan, Indonesia \\ *e-mail: saidun@unimed.ac.id
}

\begin{abstract}
Indonesian university graduates skills in creating job opportunities or entering the workforce are still low. It can be seen from the facts that the undergraduate unemployment rate is still higher than the national unemployment rate. Although entrepreneurship education has been considered as one solution to this problem, the best entrepreneurship education model has not been agreed among researchers. This study examines the application of Business Model Canvas (BMC) on enhancing student achievement and student entrepreneurial intentions and the interaction of entrepreneurial learning achievement levels and the application of BMC on entrepreneurial intentions. The method used in this research is quasi-experiment by assigning two classes of entrepreneurship courses at the Faculty of Economics, Medan State University, one class as an experimental class (BMC) and the other class as the control class. Hypothesis testing was conducted with t-test and ANOVA. The findings showed that the average entrepreneurial learning achievement of the BMC class was $12.52 \%$ higher than that of the control class. Entrepreneurial intentions of the BMC class was only $6.15 \%$ higher than that of the control class. BMC is proven to be positive and significantly improves learning achievement. The level of learning achievement is proven to be positive and it significantly increases entrepreneurial intentions. However, BMC learning has not been proven to increase entrepreneurial intentions. The results of this study are useful for entrepreneurial instructors to design learning that can increase entrepreneurial intentions.
\end{abstract}

Keywords: BMC, entrepreneurial intention, learning outcome

PENGARUH PEMBELAJARAN BUSINESS MODEL CANVAS (BMC) TERHADAP PRESTASI BELAJAR DAN MINAT BERWIRASWASTA

\begin{abstract}
Abstrak: Kemampuan lulusan perguruan tinggi Indonesia bersaing atau menciptakan lapangan kerja belum optimal. Tingkat pengangguran sarjana justru lebih tinggi dibandingkan pengangguran nasional secara total. Selama ini pendidikan kewirausahaan telah diselengarakan untuk mengatasinya. Akan tetapi, belum ada kesepakatan para ahli perihal model pendidikan kewirausahaan. Penelitian ini menguji dampak penerapan pembelajaran kewirausahaan Business Model Canvas (BMC) terhadap peningkatkan prestasi belajar dan intensi kewirausahaan mahasiswa dan bagaimana interaksi tingkat prestasi belajar kewirausahaan dan penerapan BMC terhadap intensi kewirausahaan. Metode yang digunakan adalah quasi eksperimen dengan menetapkan dua kelas mata kuliah kewirausahaan di Fakultas Ekonomi Unimed. Satu kelas sebagai kelas eksperimen (kelas BMC) dan satu kelas kontrol. Pengujian hipotesis dengan uji " $\mathrm{t}$ " dan anova. Temuan menunjukkan rata-rata prestasi belajar kewirausahaan kelas BMC lebih tinggi 12,52\% dari pada kelas kontrol. Intensi kewirausahaan kelas BMC skor rara-ratanya hanya lebih tinggi 6,15\%. Pembelajaran kewirausahaan dengan BMC terbukti positif dan signifikan dapat meningkatkan prestasi belajar. Tingkat prestasi belajar terbukti positif dan signifikan dapat meningkatkan intensi kewirausahan. Akan tetapi, pembelajaran BMC tidak terbukti dapat meningkatkan intensi kewirausahaan. Hasil penelitian ini berguna bagi pengajar kewirausahaan untuk merancang pembelajaran kewirausahaan yang dapat meningkatkan intensi kewirausahaan.
\end{abstract}

Kata Kunci: BMC, intensi kewirausahaan, prestasi belajar 


\section{INTRODUCTION}

Higher education, only able to produce job seekers, and very rarely are willing and able to create jobs, both for themselves and others. Even the job seekers produced are not ready for use, both in terms of knowledge, skills, and attitudes. So that tertiary graduates prefer to look for work rather than create their jobs. This condition causes the unemployment rate at the undergraduate level in February 2018 to be $6.31 \%$, higher than the national total of $5.13 \%$ and in February 2019 the unemployment rate at the undergraduate level also remains higher, at $6.24 \%$ and nationally total of $5.01 \%$ (BPS, 2019). So the bachelor's program as explained in the Law of Republic of Indonesia number 12 year of 2012 article 18 paragraph 2 concerning Higher Education is responsible to prepare students to be cultured intellectuals and/or scientists, able to enter and/or create jobs, and able to develop themselves into professionals yet works well.

This phenomenon is the impact that the entrepreneurial intentions of Indonesian students are still weak (Indarti \& Rostiani, 2008). Meanwhile, Krueger \& Carsrud (1993) state that entrepreneurial intentions are the best predictors for entrepreneurial actors. That is why entrepreneurial intentions urgently to be known and improved. Entrepreneurship education is vital to help increase entrepreneurial intentions (Nowiński, Haddoud, Lančarič, Egerová, \& Czeglédi, 2017). Entrepreneurship education provides knowledge and influences students' mindset. Not only that, ntrepreneurship education can influence the attitudes and aspirations of young people towards entrepreneurship (Robles \& Zárraga, 2015). Furthermore, entrepreneurship knowledge (learning achievement) possessed a significant positive correlation with entrepreneurial intentions (Doğan, 2015). Meta analysis result conducted by Mikic, Sopta, \& Horvatinovic (2018) also shows a positive relationship between entrepreneurship education and entrepreneurial intentions, this confirms the success of the current entrepreneurship education program and the importance of further enhancing and developing these programs.

Globally, entrepreneurship education is the fastest-growing field of education (Sirelkhatim \& Gangi, 2015). In the European Union introduces high-quality entrepreneurship education to equip knowledge, and enhance the attractiveness of entrepreneurial careers to young people (Jakubczak \& Rakowska, 2013). In Indonesia, efforts to foster entrepreneurial enthusiasm were carried out through Presidential Instruction of the Republic of Indonesia Number 4, 1995 concerning the "National Movement to Promote and Cultivate Entrepreneurship." In 2008 the Ministry of Cooperatives and SMEs launched the National Shoot Entrepreneurship Movement program for high school and tertiary students (Murtini, 2008). Then since 2009, universities in Indonesia must put entrepreneurship courses into the curriculum as compulsory subjects in 2 semesters.

However, the degree to which entrepreneurship education affects students is still a matter of debate in various circles (Fiet, 2001). The debate is related to the accuracy and effectiveness of entrepreneurial teaching methods (Westhead, Storey, \& Martin, 2001). Čapienė \& Ragauskaitè (2018) supports entrepreneurial teaching methods by increasing collaboration between entrepreneurship education stakeholders and bringing them closer to the business environment. Kyro (2003) states entrepreneurship education must focus on learning activities that can enhance understanding, business knowledge and entrepreneurship. Entrepreneurship learning at the university examines theoretical aspects and practical knowledge (Heinonen \& Poikkijoki, 2006). Therefore entrepreneurial instructors must have the knowledge, experience and practical skills on how to start a business (Purwana, Suhud, \& Wibowo, 2018).

The role of entrepreneurship education in increasing entrepreneurship is frequently essential. Although until now there has been no research that states what learning models are the most effective in increasing entrepreneurial intentions, there are at least two ways that can be done in teaching entrepreneurship, namely through the business plan model and Business Model Canvas. In 2004, Alexander Osterwalder introduced the Business Model Canvas (BMC). BMC is an abstract concept of a business model that represents business strategies and processes (Osterwalder \& Pigneur, 2010). BMC is a tool to describe business models based on nine elements (Osterwalder, 2004; Fritscher \& Pigneur, 2014). This model illustrates and visualizes business ideas that are planned and 
suitable for innovative startup companies (Alias, Goudz, Jawale, \& Noche, 2015). Türko (2016) has conducted research on students' perceptions of entrepreneurial learning that applies the business plan model and BMC. The result, $62 \%$ of students stated that it was difficult to prepare on busines plan model because it was more complicated, longer and tedious.

Meanwhile, the BMC is easier to understand because business logic has been summarized in $\mathrm{BMC}$. BMC is able to explain business value and feasibility propositions through concise logic. Coes (2014) also explained the power of BMC being able to visually represent business models, the simplicity of designing and communicating business models to employees, partners and customers. Fritscher \& Pigneur (2014) added that the advantages of BMC are visual modelling methods that can capture the business model of a company. Research on BMC has so far been limited to its benefits in preparing business plans, and no research has been found that examines the role of BMC in increasing entrepreneurial intentions.

This study examines the learning role of BMC through the final task of making a business plan on one page with nine business area blocks. The goodness of this model can be used for each business model. Another advantage is that students are required from the beginning to know who their business partners are, the main activities of the business, the value offered, channels, customer segmentation, key resources, cost structures and business profit potential. Through this BMC, students from the beginning are more realistic and comprehensive in understanding a business. Therefore, this is thought to increase entrepreneurial intentions.

\section{METHOD}

This research uses the quasi-experimental method carried out on the campus of the Faculty of Economics, Medan State University. This study is based on constructivist learning theories that demand students' independence to formulate a business idea, design business, and report it. Students are allowed to set their learning process to complete business plan tasks. The study population was all entrepreneurship classes at the Faculty of Unimed in the odd semester of 2018, amounting to 15 classes. Each class has a relatively homogeneous condition because it is in semester $\mathrm{V}$ and has not gotten an entrepreneurship course in the previous semester. Class samples were determined as many as two classes utilizing purposive sampling with consideration of equal teaching staff. One class as a BMC treatment (experimental class) and the other class as a control class did not apply BMC, determined by simple random sampling.

Data collection techniques used were instruments consisting of: (a) instrument (test) of entrepreneurial learning outcomes, and (b) entrepreneurial intentions (adopted from Liñán \& Chen, 2009; Liñán, Rodríguez-Cohard, \& RuedaCantuche, 2011) on a scale of 1-7. A score of 1 describes "very weak," and a score of 7 describes "very strong.". Before being distributed, the learning achievement test instrument was tested to ensure validity. Normality and homogeneity tests are carried out to ascertain whether the data is normally distributed and homogeneous as a condition of using a hypothesis test tool. To measure the impact of BMC entrepreneurship learning, researchers using "t-test" and "anova test". The tool for running statistical test is using SPSS version 24 .

Table 1. Variable and Indicator

\begin{tabular}{clll}
\hline No. & \multicolumn{1}{c}{ Variable } & \multicolumn{1}{c}{ Indicator } & \multicolumn{1}{c}{ Item } \\
\hline 1. & Entrepreneurship learning outcomes & Business opportunities, & 5,14 \\
& & Entrepreneurial character & $3,4,7,8,9,12,16$ \\
& Entrepreneurial process & 10,17 \\
& Resources & $1,2,11,15$ \\
& & Business planning & $6,13,18$ \\
$2 . \quad$ Entrepreneurial intension & Work orientation & 1,2 \\
& & Readiness to start a business & 3,6 \\
& & Entrepreneurial determination & 4,5 \\
\hline
\end{tabular}




\section{RESULT AND DISCUSSION Result}

The number of questions used to measure the level of entrepreneurial knowledge of students was 17 multiple choice items. Moreover, that to find out students' ability to build a business, an assignment is given to build business plans in groups. Students first tested the questions. From 20 multiple choice items tested, there were 17 items valid (with criteria rpbis $>$ .361). Then from the 6 statement items used to measure student entrepreneurial intentions, all of them can be used, seen from the validity with the lowest Corrected Item-Total Correlation score of .681 and the highest .824 (with criteria $>.30$ ) and Alpha Cronbach .912 (with criteria > .60).

\section{Students Response Toward Tools and Implementation of BMC Learning}

The principle of the reaction of BMC learning is seen from the responses given by students to the learning instruments and the application of BMC, and the results are presented in Table 2.
Student responses to the application of BMC viewed from 5 aspects; happy and unhappy feelings, aspects of learning new categories or not, the level of language clarity, the level of understanding, and the level of exciting or unexciting on the BMC Student Worksheet and learning outcomes test, the result is that every aspect received a positive response in $81 \%$ and above (category " very high"). Calculation results are presented in Table 2 .

A pretest was performed to find out the initial conditions of the students' abilities, and the results are presented in Table 3 . The data were proven to be normally distributed between the BMC class and the control class because each sig value $>.05$ both the KolmogorovSmirnov and Shapiro-Wilk tests. Then the homogeneity of the data is also fulfilled because of the sig Test of Homogeneity of Variances $>.05$. These results state there is no difference in the ability of BMC class students with control classes.

\section{Tabel 2. Student Responses to BMC Learning Instruments and Implementation}

\begin{tabular}{|c|c|c|c|}
\hline \multirow{2}{*}{\multicolumn{2}{|c|}{$\begin{array}{l}\text { Aspects } \\
\text { Feelings of "Happy or Unhappy" Respondents to the component; subject } \\
\text { matter, BMC Model. Student Worksheet (Business Plan), learning } \\
\text { atmosphere, instructor/lecturer appearance, how to teach }\end{array}$}} & \multicolumn{2}{|c|}{ Average Response (\%) } \\
\hline & & $\begin{array}{c}\text { Happy } \\
100\end{array}$ & $\begin{array}{c}\text { Unhappy } \\
0\end{array}$ \\
\hline \multicolumn{2}{|c|}{$\begin{array}{l}\text { "New or Not New" respondents' opinions of the components; subject } \\
\text { matter, BMC Model. Student Worksheet (Business Plan), learning } \\
\text { atmosphere, instructor/lecturer appearance, how to teach }\end{array}$} & $\begin{array}{c}\text { New } \\
85\end{array}$ & $\begin{array}{l}\text { Not new } \\
15\end{array}$ \\
\hline \multicolumn{2}{|c|}{$\begin{array}{l}\text { "Clear or Unclear" respondents' opinions about the language used in the } \\
\text { Student Worksheet and learning achievement test }\end{array}$} & $\begin{array}{l}\text { Clear } \\
96.55\end{array}$ & $\begin{array}{l}\text { Unclear } \\
3.50\end{array}$ \\
\hline \multicolumn{2}{|c|}{$\begin{array}{l}\text { Respondents' opinions about "understanding or not understanding” of the } \\
\text { Student Worksheet (Business Plan) and learning achievement test }\end{array}$} & $\begin{array}{l}\text { Understand } \\
93\end{array}$ & $\begin{array}{l}\text { Not Understand } \\
7.00\end{array}$ \\
\hline \multicolumn{2}{|c|}{$\begin{array}{l}\text { Respondents' opinions about the "exciting or unexciting" towards Student } \\
\text { Worksheets (Business Plan) and test results }\end{array}$} & $\begin{array}{c}\text { Exciting } \\
89.50\end{array}$ & $\begin{array}{l}\text { Unexciting } \\
10.50\end{array}$ \\
\hline $\begin{array}{l}\text { iteria: } 0 \%-20 \% \\
21 \%-40 \% \\
41 \%-60 \% \\
61 \%-80 \% \\
81 \%-100 \%\end{array}$ & $\begin{array}{l}\text { Very low } \\
\text { Low } \\
\text { Medium } \\
\text { High } \\
\text { Very high }\end{array}$ & & \\
\hline
\end{tabular}

Table 3. Test Results for Normality and Homogeneity in Pretest

\begin{tabular}{llll}
\hline & & BMC Classroom & Control Classroom \\
\hline Number & & 33 & 31 \\
Average learning achievements & 61.121 & 57.710 \\
Normality test & Kolmogorov-Smirnov & .167 & .200 \\
& Shapiro-Wilk & .357 & .238 \\
Test of Homogeneity of & Levene Statistic & .106 & \\
Variances & Sig. & .746 & \\
\hline
\end{tabular}


The next step is to test the assumptions of normality and homogeneity. Referring to Table 4, entrepreneurial learning achievement data for BMC class and control class are both normally distributed because they meet the Shapiro-Wilk requirements where sig values are .056 and $.118>.05$, respectively. Then the data on entrepreneurship intentions both the BMC class and the control class are both normally distributed because the Shapiro Wilk sig values are respectively .140 and $.549>.05$. Specifically for the normality of learning achievement only the Shapiro-Wilk criteria meet this requirement because of the small sample size.

Furthermore, the homogeneity test results of learning achievement data and entrepreneurial intention (Learning model and learning achievement level) both meet the requirements because of each sig value $>.05$ as presented in Table 5. Because the normality and homogeneity requirements of the data have been fulfilled, the next step is carried out hypothesis testing.
Furthermore, to find out whether there are differences in entrepreneurship learning outcomes between the BMC class and the control class as the impact of using learning models (BMC application and conventional learning) and the impact of the level of learning achievement the t-test is performed. The results are presented in Table 5, where learning achievement between the BMC class and the control class fulfills the homogeneity requirements because the sig values are respectively .713 and $.673>$ of .05 . Likewise, the students' entrepreneurial intentions also meet the data criteria of homogeneity because each sig value $>.05$. Then the test results of differences in learning achievement based on the output "Independent Samples Test" in the "Equal variances assumed" section known sig (2-tailed) value of $.033<.05$, (see Table 6 ) means that there are significant differences in BMC class learning outcomes with control.

Table 4. Test Results of Normality Learning Achievements and Entrepreneurial Intention

\begin{tabular}{|c|c|c|c|c|c|c|c|}
\hline & \multirow{2}{*}{ Model } & \multicolumn{3}{|c|}{ Kolmogorov-Smirnov ${ }^{a}$} & \multicolumn{3}{|c|}{ Shapiro-Wilk } \\
\hline & & Statistic & $d f$ & Sig. & Statistic & $d f$ & Sig. \\
\hline \multirow[t]{2}{*}{ Learning achievements } & $\mathrm{BMC}$ & .252 & 22 & .001 & .914 & 22 & .056 \\
\hline & Control & .242 & 20 & .003 & .924 & 20 & .118 \\
\hline \multirow[t]{2}{*}{ Entrepreneurial intention } & $\mathrm{BMC}$ & .126 & 22 & $.200^{*}$ & .933 & 22 & .140 \\
\hline & Control & .144 & 20 & $.200^{*}$ & .960 & 20 & .549 \\
\hline
\end{tabular}

Table 5. Test of Homogeneity of Variances

\begin{tabular}{lcccc}
\hline & Levene Statistic & $\boldsymbol{d f 1}$ & $\boldsymbol{d} \boldsymbol{f} \mathbf{2}$ & Sig. \\
\hline Learning achievements & .137 & & & \\
Learning model & .181 & 1 & 40 & .713 \\
Level learning achievements & & 1 & 40 & .673 \\
Entrepreneurial intention & .756 & & & \\
Learning model & .479 & 1 & 40 & .390 \\
Level learning achievements & & 40 & .493 \\
\hline
\end{tabular}

Table 6. Independent Samples Test, Learning Achievements

\begin{tabular}{|c|c|c|c|c|c|c|c|c|}
\hline & & \multicolumn{2}{|c|}{$\begin{array}{l}\text { Levene's Test } \\
\text { for Equality of } \\
\text { Variances }\end{array}$} & \multicolumn{5}{|c|}{ t-test for Equality of Means } \\
\hline & & $\mathbf{F}$ & Sig. & $t$ & $d f$ & $\begin{array}{c}\text { Sig. } \\
\text { (2-tailed) }\end{array}$ & $\begin{array}{c}\text { Mean } \\
\text { Difference }\end{array}$ & $\begin{array}{l}\text { Std. Error } \\
\text { Difference }\end{array}$ \\
\hline \multirow[t]{2}{*}{$\begin{array}{l}\text { Learning } \\
\text { achievements }\end{array}$} & $\begin{array}{l}\text { Equal variances } \\
\text { assumed }\end{array}$ & .137 & .713 & 2.206 & 40 & .033 & 7.795 & 3.534 \\
\hline & $\begin{array}{l}\text { Equal variances } \\
\text { not assumed }\end{array}$ & & & 2.211 & 39.88 & .033 & 7.795 & 3.526 \\
\hline
\end{tabular}


The difference in entrepreneurship learning achievement between the BMC class and the control class based on the average BMC class is $12.52 \%$ higher than the control class (see Table 7).

Entrepreneurship Intention Test Results BMC class with control class(conventional) seen from the total mean is not significantly different, where the average total BMC class is 37.682 and the control class is 35.50 with a difference of $6.15 \%$ (see Table 8).

Hypothesis test results of the impact of the application of the BMC model and the effect of entrepreneurial learning outcomes on entrepreneurial intentions are presented in Table 9. It is known that the Corrected Model shows a sig value of $.000<.05$, meaning that the BMC learning model and the level of entrepreneurial learning achievement together prove to have a significant effect on intention entrepreneurship. The contribution of learning models and the level of entrepreneurial knowledge in influencing entrepreneurial intentions is seen from the $R$ Squared value of $49.2 \%$.

Table 7. Learning Achievements by Class Group

\begin{tabular}{lccccc}
\hline & Model & $\boldsymbol{N}$ & Mean & Std. Deviation & Std. Error Mean \\
\hline Learning achievements & BMC & 22 & 70.046 & 11.668 & 2.488 \\
& Control & 20 & 62.250 & 11.177 & 2.499 \\
\hline
\end{tabular}

Table 8. Entrepreneurial Intention Based on Class and Level of Learning Achievements

\begin{tabular}{|c|c|c|c|c|}
\hline Model & Level of Learning Achievements & Mean & Std. Deviation & $N$ \\
\hline \multirow[t]{3}{*}{$\mathrm{BMC}$} & Low & 35.545 & 2.841 & 11 \\
\hline & High & 39.818 & 1.991 & 11 \\
\hline & Total & 37.682 & 3.242 & 22 \\
\hline \multirow[t]{3}{*}{ Control } & Low & 34.600 & 2.271 & 10 \\
\hline & High & 38.400 & 1.713 & 10 \\
\hline & Total & 36.500 & 2.763 & 20 \\
\hline \multirow[t]{3}{*}{ Total } & Low & 35.095 & 2.567 & 21 \\
\hline & High & 39.143 & 1.957 & 21 \\
\hline & Total & 37.119 & 3.046 & 42 \\
\hline
\end{tabular}

Tabel 9. Test of Between-Subjects Effects

Dependent Variable: Entrepreneurial Intention

\begin{tabular}{lccccc}
\hline Source & $\begin{array}{c}\text { Type III Sum of } \\
\text { Squares }\end{array}$ & $d f$ & Mean Square & $\boldsymbol{F}$ & Sig. \\
\hline Corrected model & $187.241^{\mathrm{a}}$ & 3 & 62.414 & 12.278 & .000 \\
Intercept & 57649.870 & 1 & 57649.870 & 11341.136 & .000 \\
Model & 14.632 & 1 & 14.632 & 2.878 & .098 \\
LevelLearning achievements & 170.681 & 1 & 170.681 & 33.577 & .000 \\
Model * levelLA & .585 & 1 & .585 & .115 & .736 \\
Error & 193.164 & 38 & 5.083 & & \\
Total & 58249.000 & 42 & & & \\
Corrected total & 380.405 & 41 & & & \\
\hline a $R$ Squan & & & & &
\end{tabular}

a. $R$ Squared $=.492$ (Adjusted $R$ Squared $=.452)$ 
Partially the BMC model was not proven to be able to increase entrepreneurial intentions because the sig value was .98 $>.05$. However, the high and low levels of entrepreneurial learning achievement proved to significantly influence entrepreneurial intentions because the sig value of $.000<.05$. Then the results of the interaction test of learning models (BMC and control) and the level of entrepreneurial learning achievement towards entrepreneurial intentions are not proven, because the sig value of $.736>$ .05 .

\section{Discussion}

The essence of learning entrepreneurship by applying business Model Canvas is making a business plan. The business plan is summarized in 9 blocks.Based on the canvas, a more detailed business plan has been prepared. Before preparing a business plan, students are equipped with various business-related knowledge and skills such as; the ability to recognize business opportunities, the ability to take advantage of these opportunities, the ability to organize needed resources, the ability to think critically and creatively, and the ability to prepare financial reports. How to fill each block and the order in which to fill the blocks are presented in Figure 1.
Knowledge and skills about a business that students already have are very helpful for filling every area of the nine BMC blocks and preparing business plans. The preparation of a business plan starts by finding a business idea. The business idea must be based on creativity and have favorable prospects. Then the business idea was poured in one sheet of canvas paper. Entrepreneurship learning with BMC makes it easy for students to understand a business comprehensively. Students who have no experience of business find it difficult to draw up business plans. However, with this BMC pursuit, students are required to be able to fill each of the nine existing blocks. Each block is related to one another. If students can fill all nine blocks and are related to one another, they have understood the business plan that they will realize. The stages are filled in the following sequence.

First, the Customer segment block, at this stage, students must be able to determine who their customer segment is. The customer segment is to whom the goods or services we offer. Previously it must be known what their needs are not being met and they need. Business ideas usually arise from opportunities. Opportunities, in this case, are the needs of consumers who have not been met, whether they know or do not know

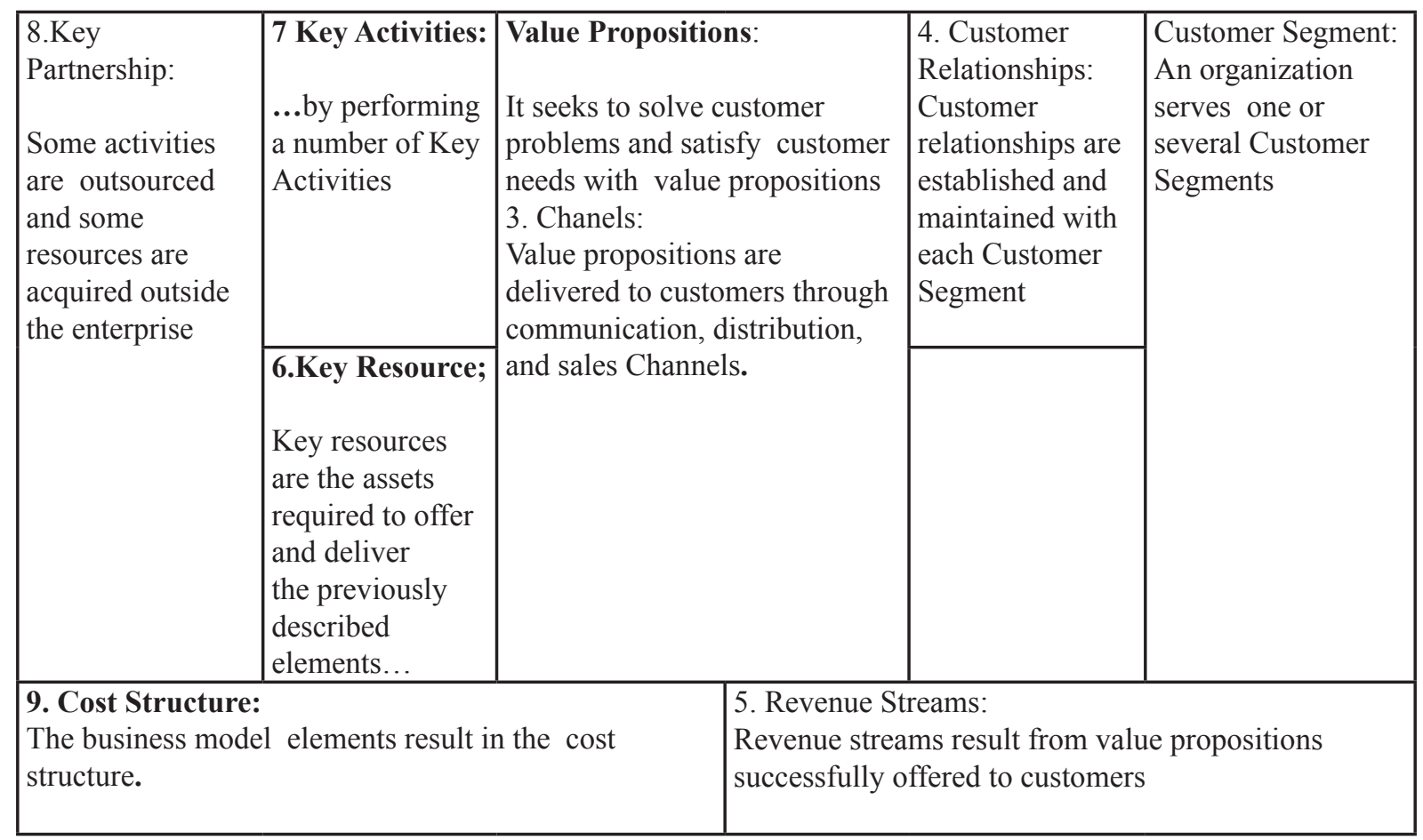

Figure 1. BMC: Nine Business Model Building Blocks

(Osterwalder\& Pigneur, 2010) 
it. Solihah, Hubeis, \& Maulana (2014) explains an organization must decide which segments are served and which are ignored, after that, then design the right business model according to needs.

If consumers are not aware of their needs, the seller will introduce them so that consumers are aware of them. Here students need creative ideas to be able to find new business opportunities. Recognizing potential customers can be from various perspectives such as; geographical, demographic, and psychographic. These different characteristics make the type of needs they will also be different.

Second, Value propositions, students must be able to determine the value that is offered to consumers, and that cannot be given by competitors. The ability of new businesses to enter the market and be able to compete with businesses that already exist in the market lies in the added value or something unique that they offer to consumers. Consumers accept this, and they feel it is a necessity and then makes a transaction. Hermawan \& Pravitasari (2010) states that if the Value Propositions offered can address the needs or satisfy the needs of consumers can divert the attention of consumers from one company to another company.

Third, Chanel, in this block, students must be able to determine how to deliver or sell products/services to buyers. What media or means do we use to sell our products to consumers? The media used must be in accordance with the development of information technology or digital-based such as Google, Yahoo, Altavista, Exclopedia, Wikipedia, and others. The market orientation that is designed should not be limited to the local market but rather to a broader national market, even globally depending on the nature of the product it has.

Fourth, Customer Relationships, in this case, students must be able to design how to guarantee good relations with consumers. Maintaining good relations with consumers is one of the business strategies that students must master from the start. Fifth, Revenue Stream, students must know the primary source of income for the planned business. The main income comes from the sale of their products. Besides, that income can come from selling products from third parties. Sixth, Key Resources, from the beginning, students must be able to determine the resources that must be had to run the main activities of the business. Key resources can be in the form of physical resources (buildings, vehicles, equipment), money, intellectual assets (brands, copyrights, patents, customer databases), and human resources.

Seventh, Key Activities, in this case, students must know the main activities in their business. If students already know the main activities in business, it means that their mastery over the planned business is better. Key activities that determine the success of the business in delivering value propositions to the customer segment. Eighth, Key Patnership, this is related to who the business partners are suppliers of cheap and quality goods, freight forwarding services (JNE, TNT, post offices, and others), advertising agencies, marketplaces (tokopedia, bukalapak, zalora, Shoope, JD .id, etc.). The eighth final step, Cost structures, from the beginning, students can already know what types of costs must be incurred. If the type of trading business consists of the cost of purchasing goods, advertising costs, shipping costs, internet costs, and company employee costs. If students are able to fill the nine blocks that are well available and related to one another, then they already understand the business as a whole. This knowledge and experience will benefit them if they realize their business both when they are students and after graduating from college.

BMC learning received a good response from students. All students said BMC learning was fun because they could collaborate in designing business independently. As many as $85 \%$ of students stated that BMC learning was new and different from previous learning. Furthermore, BMC learning is clear, easy to understand, and enjoyable. Of the five aspects observed, $81 \%$ of students responded above and are in the "very high" category. When viewed by student activities, they are encouraged to participate actively both individually and in groups. Learning like this makes them able to work in teams (teamwork), each team member has the responsibility to complete their group assignments.

Then, when viewed from the level of understanding, it can be concluded that the understanding of students is excellent because they can pour business ideas on a canvas sheet 
by filling in every block and its contents related between one block and another block. Examples of student group work are presented in Figure 2. From the students' assignments, it is known that they can find creative-based business ideas, can set customer segments and can show value propositions or the advantages of their products or services compared to competitors. Students have also been able to determine what strategies will be taken to deliver products or services to prospective buyers or customers. In general, the ability of students in each group is relatively the same. This BMC entrepreneurial learning experience will be useful later if they build their businesses or work with others.

Based on the results of data analysis, as reported in Table 8, it was found that BMC learning and entrepreneurial learning outcomes together proved to have a significant effect on entrepreneurial intentions. The results of this study support research (Ismail, Khalid, Othman, Jusoff, Rahman, Kassim, \& Zain, 2009; Kusmintarti, Thoyib, Maskie, \& Ashar, 2016) which states entrepreneurship courses or training, (Gerba, 2012; Premand, Brodmann, Almeida, Grun, \& Barouni, 2016); Patricia \& Silangen, 2016; Nowiński et al., 2017) entrepreneurship education contributes to entrepreneurial intentions. Then, Dehghanpour (2013) added that the entrepreneurship course that was followed could increase entrepreneurial intentions. Furthermore, Kusmintarti et al. (2016) added that people who participated in entrepreneurship training had the provision of business ideas and social networking and had the desire to build a business going forward. This research provides a theoretical foundation for the development of entrepreneurial intentions through entrepreneurial learning.

Entrepreneurship education is increasingly attracti ng the attention of researchers. Raposo \& Paço (2011) state that entrepreneurship education provides knowledge in the form of; (a) the ability to recognize opportunities, (b) the ability to take advantage of opportunities, generate new ideas and find needed resources, (c) the ability to create and operate new devices, and (d) the ability to think critically and creatively. According to Sánchez (2011), in addition to business knowledge and skills, entrepreneurship education also develops beliefs, values, and attitudes, and aims to make students confident and consider entrepreneurship as an alternative job or as unemployment. Furthermore, Ismail et al. (2009) stated that the entrepreneurship course, Fayolle \& Gailly (2015) added that entrepreneurship education has a positive effect on students who either have low or non-existent entrepreneurial intentions.

The completion of one entrepreneurship course can increase entrepreneurial intentions by 1.3 times (Dehghanpour, 2013). Then, Martin, McNally, \& Kay (2013) found a significant relationship between Entrepreneurship Education and Training (EET) with the preparation of entrepreneurial human capital assets. Kusmintarti et al. (2016) stated similarly that students who participated in entrepreneurship
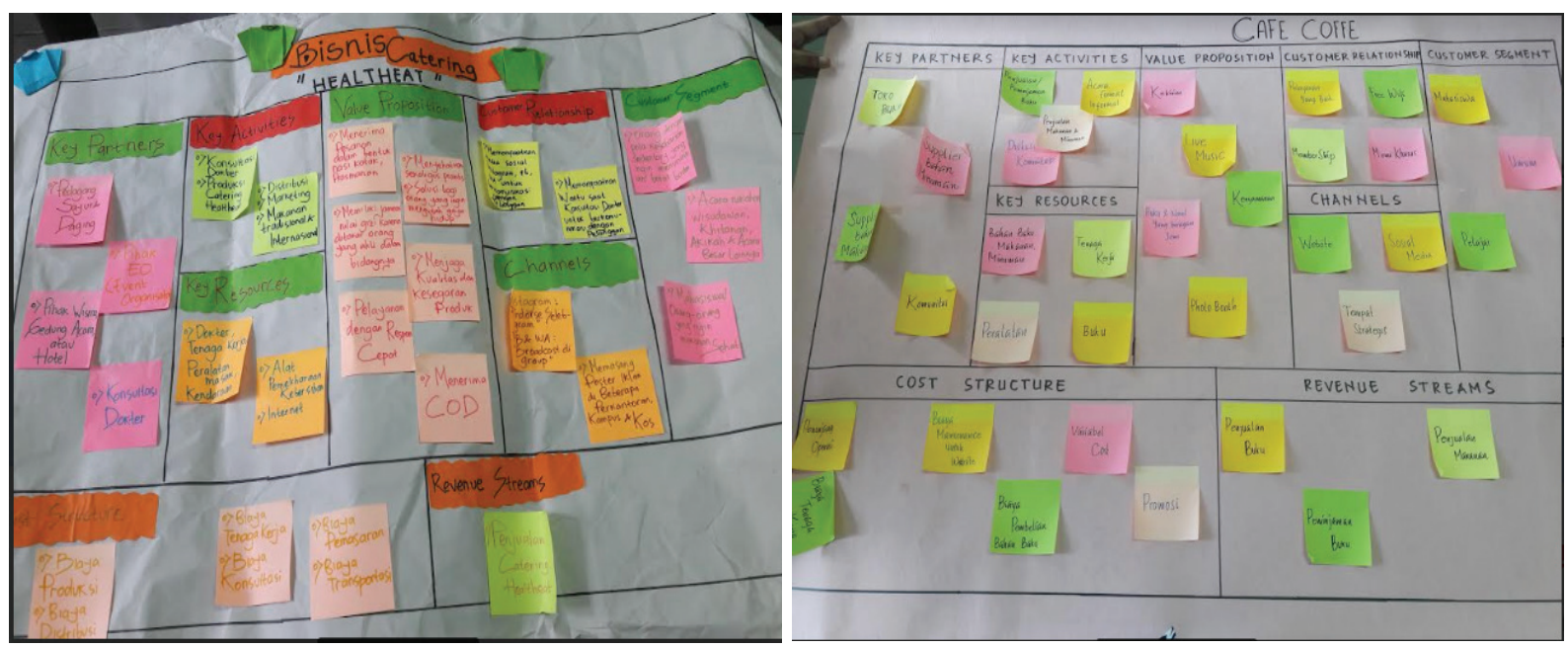

Figure 2. Examples of BMC Students' Assignment 
training had the intention to build a new business in the future because they were equipped with business ideas and social networking. Previously Nursito, Julianto, \& Nugroho (2013) stated that entrepreneurship education could shape entrepreneurial knowledge and have a positive and significant impact on entrepreneurial intentions. Therefore, Barba-Sánchez \& Atienza-Sahuquillo (2017) need to integrate entrepreneurship education with technical education to increase entrepreneurial intentions. The focus of entrepreneurship education is to develop entrepreneurial attitudes, skills, and entrepreneurial behavior (Doğan, 2015). The results of the latest research, Solesvik (2019) explains that business education positively influences the formation of entrepreneurial skills and competencies. Students who study business also exhibit higher levels of entrepreneurial intentions than those who do not participate in business education.

Čapienė \& Ragauskaitė (2018) support the entrepreneurship teaching method by increasing collaboration between stakeholders in entrepreneurship education and getting closer to the business environment. Kyro (2003) states entrepreneurship education must focus on learning activities that can enhance understanding, business knowledge, and entrepreneurship. Entrepreneurship learning in universities examines theoretical aspects and practical knowledge (Heinonen \& Poikkijoki, 2006). Therefore entrepreneurial instructors must have the knowledge, experience and practical skills on how to start a business (Purwana et al., 2018).

Furthermore, the partial test results of the application of BMC have not been proven to increase entrepreneurial intentions. This means that there is no difference in the entrepreneurial intentions of students taught by BMC with the control class. So far, no research has been found that examines the effect of BMC learning on entrepreneurial intentions so that none can be used as a comparison. However, the use of BMCs in the field of financial management allows companies to identify customer needs, estimate the potential benefits and costs required (Dudin, Kutsuri, Jur, \& Sozrykoevna, 2015). Furthermore, Crotty, Kinney, \& Farren (2017) state that BMC learning is simple, clear, and how business strategy is centered on nine main business area blocks, and more importantly, encourages students or business people to think about how interactions and consequences occur.

Research conducted by Dewobroto (2013) states that the use of Business Model Canvas can be a simple tool to produce an alternative strategy for the company to achieve financial viability. Then, Dudin, Lyasnikov, Leont'eva, Reshetov, \& Sidorenko (2015) stated that the use of the business model of the canvas model could create a competitive advantage in the agricultural industry due to the organizational features of the production and sales cycle. Toro-Jarrín, Ponce-Jaramillo, \& GüemesCastorena (2016) also argued that Business Model Canvas identifies essential parts of the business, the simplicity of its application makes it more acceptable and disseminated. Furthermore, Lima \& Baudier (2017) states that $\mathrm{BMC}$ is expected to not only be able to improve organizational performance, enhance the ability of entrepreneurs to communicate, and innovate their business models but also as tools that are adapted for visualization, decision making, creative thinking, collaboration, and reflection.

Entrepreneurial learning, according to Fruchter (2001) needs to change from traditional teaching practices centered on teaching to "knowing-what," to active learning with a focus on teaching to "know-why." BMC learning includes active and student-centered learning. Student-centered learning makes them more independent and responsible for finding solutions; educators play a role as mentors or facilitators (Doppelt, 2003). The advantages of active learning are very relevant in the field of entrepreneurship, where students have the goal to create and lead their projects, and become a favorite practice for teaching entrepreneurship (Åsvoll \& Jacobsen, 2012). Rae (2011) also proposes that entrepreneurship education requires a holistic and activity-based approach. This model is useful for understanding learning material, practice, and personal development of social and group interactions. Active learning activities make academic results and higher motivation, and more in-depth understanding of content, and have been proven in several studies (Michael, 2006).

The next finding is that the level of entrepreneurial learning achievement has been proven to influence entrepreneurial intentions. 
This means that student entrepreneurship intentions will be higher if entrepreneurship learning achievement is high, and vice versa, entrepreneurial intentions will be lower in students with lower entrepreneurial learning achievements. High levels of student achievement, illustrating their mastery of entrepreneurial knowledge is higher. In general, entrepreneurial knowledge includes business planning, business development strategies, attitudes, and records and finance. Suryana \& Bayu (2010), explained that an entrepreneur must know the business to be initiated and knowledge of the business environment that will affect entrepreneurial activities; knowledge of roles and responsibilities; knowledge of personality and responsibilities; and the latest knowledge is knowledge about management and business organizations.

Mastery of entrepreneurial knowledge (learning achievement) is essential. Knowledge aboutentrepreneurshipinfluences entrepreneurial intentions positively and significantly (Anggraeni \& Harnanik, 2015; Hutasuhut, 2018; Doğan, 2015, 2015; Roxas, Cayoka, \& Jesus, 2008). Mastery of entrepreneurial knowledge will increase the ability of students to run businesses. When he feels he has the ability, there will be an intention to run a business. Previous researchers such as (Roxas, 2014; Küttim, Kallaste, Venesaar, \& Kiis, 2014) stated that entrepreneurship education significantly increased entrepreneurial knowledge. Entrepreneurial knowledge is the basis of entrepreneurial resources found in individuals (Hisrich, Peters, \& Shepherd, 2008). The results of this research strengthen the theoretical foundation of the importance of providing education in higher education to build entrepreneurs. Entrepreneurship education can help and increase entrepreneurial awareness and acceptance as a valuable career choice (Mikic et al., 2018). Entrepreneurship education is also able to provide knowledge to recognize opportunities, take advantage of opportunities, create and operate new devices, and the ability to think critically and creatively (Robles \& Zárraga, 2015). Raposo \& Paço (2011) added that entrepreneurship education could be competencies and attitudes that can determine future carrier choices.

Further findings, this research did not succeed in proving an interaction between the application of the BMC model and the level of knowledge (entrepreneurial learning achievement) in shaping student entrepreneurial intentions. This is because partially, the BMC learning model does not have an impact on increasing entrepreneurial intentions even though the level of achievement has a partial impact. Although the application of BMC learning directly has not been proven to be able to increase the entrepreneurial intentions of students. However, this research succeeded in proving that the application of BMC can improve entrepreneurial learning outcomes and through moderation of the level of knowledge (learning achievement of entrepreneurship), is proven to increase entrepreneurial intentions. The results of this research strengthen the theoretical foundation of the importance of entrepreneurship education to increase knowledge about entrepreneurship in order to create a generation that is interested in entrepreneurship.

\section{CONCLUSION}

Application of Business Model Canvas (BMC) on entrepreneurial learning can be a positive response from students and can increase entrepreneurship learning outcomes, experimental class learning outcomes (BMC) $12.52 \%$ higher than the control class learning outcomes. However, the entrepreneurship intentions of BMC class students were not proven to be higher than the control class. However, together, the application of BMC and the level of entrepreneurial learning achievement can increase student entrepreneurial intentions. The class learning process that applies BMC can create a pleasant learning atmosphere for all students (100\%) who feel understood 93\% and feel drawn $89.5 \%$. This research provides a theoretical foundation that the development of entrepreneurial intentions can be done through entrepreneurship education. Entrepreneurship education can increase knowledge (entrepreneurial learning achievement), and achievement levels can strengthen (moderate) $\mathrm{BMC}$ learning to increase entrepreneurial intentions. For this reason, universities are expected to be able to design practical and coherent entrepreneurial learning that combines conceptual learning and practical learning. This study has limitations in duration and class of treatment, so it is possible to be reviewed again by adding a broader duration and class. 


\section{ACKNOWLEDGEMENT}

The researcher thanked the Rector of Medan State University for financial assistance through the Lecturer Study Group Research Grant program and grateful also to the Dean of the Faculty of Economics for the research permission given and thanks to the students for their participation in this research.

\section{REFERENCES}

Alias, C., Goudz, A., Jawale, M., \& Noche, B. (2015, May). Generating a business model canvas for future-internet-based logistics control towers. Proceeding of the 2015 $4^{\text {th }}$ International Conference on Advanced Logistics and Transport (ICALT), 257262.

Anggraeni, B., \& Harnanik, H. (2015). Pengaruh pengetahuan kewirausahaan dan lingkungan keluarga terhadap minat berwirausaha siswa kelas XI SMK Islam Nusantara Comal Kabupaten Pemalang. [The influence of entrepreneurial knowledge and family environment on the entrepreneurial interest of XI grade students of SMK Islam Nusantara Comal, Pemalang Regency]. Dinamika Pendidikan, 10(1), 42-52. doi:10.15294/ dp.v10i1.5093.

Åsvoll, H., \& Jacobsen, P. J. (2012). A case study: Action based entrepreneurship education how experience problems can be overcome and collaboration problems mitigated. Journal of Entrepreneurship Education, 15(SI), 75-97. https:// ntnuopen.ntnu.no/.

Barba-Sánchez, V., \& Atienza-Sahuquillo, C. (2017). Entrepreneurial intention among engineering students: The role of entrepreneurship education. European Research on Management and Business Economics, 24(1), 53-61. doi:10.1016/j. iedeen.2017.04.001.

BPS. (2019). Pengangguran Terbuka Menurut Pendidikan tertinggi yang ditamatkan 1986-2018. Tersedia: Http://Www. Bps. Go. Id/.
Čapienė, A., \& Ragauskaite, A. (2018). Entrepreneurship education at university: Innovative models and current trends, 2, 284-291. doi:10.22616/rrd.23.2017.080.

Coes, D. H. (2014). Critically assessing the strengths and limitations of the Business Model Canvas (Master's thesis, University of Twente). https://essay.utwente.nl/.

Crotty, Y., Kinney, T., \& Farren, M. (2017). Using the Business Model Canvas ( BMC) strategy tool to support the Play4Guidance online entrepreneurial game, 4(1), 34-41. doi:10.1515/ijtr-2017-0005.

Dehghanpour, A. (2013). The process of impact of entrepreneurship education and training on entrepreneurship perception and intention: Study of educational system of Iran. Education and Training, 55(8-9), 868-884. doi:10.1108/ET-04-2013-0053.

Dewobroto, W. S. (2013). Penggunaan Business Model Canvas Sebagai Dasar Untuk Menciptakan Alternatif Strategi Bisnis dan Kelayakan Usaha. Jurnal Teknik Industri, I(2), 215-230.

Doğan, E. (2015). The effect of entrepreneurship education on entrepreneurial intentions of university students in Turkey. The Journal of Entrepreneurship, 23(1), 1-18. doi:10.1177/0971355713513346.

Doppelt, Y. (2003). Implementation and assessment of project-based learning in a flexibleenvironment.Internationaljournal of technology and design education, 13(3), 255-272. doi:10.1023/A:1026125427344.

Dudin, M. N., Kutsuri, G. N., Jur, I., \& Sozrykoevna, S. (2015). The innovative Business Model Canvas in the system of effective budgeting, 11(7), 290-296. doi:10.5539/ass.v11n7p290.

Dudin, M. N., Lyasnikov, N. V. E., Leont'eva, L. S., Reshetov, K. J. E., \& Sidorenko, V. N. (2015). Business model canvas as a basis for the competitive advantage of enterprise structures in the industrial agriculture. 
Biosciences Biotechnology Research Asia, 12(1), 887-894. doi:10.13005/bbra/1736.

Fayolle, A., \& Gailly, B. (2015). Fayolle, A., \& Gailly, B. (2013). The impact of entrepreneurship education on entrepreneurial attitudes and intention: Hysteresis and persistence. Journal of Small Business Management, 53(1), 7593. doi:10.1111/jsbm. 12065.

Fiet, J. O. (2001). The theoretical side of teaching entrepreneurship. Journal of business venturing, 16(1), 1-24. doi:10.1016/ S0883-9026(99)00041-5.

Fritscher, B., \& Pigneur, Y. (2014). Visualizing business model evolution with the Business Model Canvas: Concept and tool. Proceedings of the 2014 IEEE 16th Conference on Business Informatics, 151158. doi:10.1109/CBI.2014.9.

Fruchter, R. (2001). Dimensions of teamwork education. International Journal of Engineering Education, 17(4/5), 426430. https://dialnet.unirioja.es/servlet/ revista? $\operatorname{codigo}=14394$.

Gerba, D. T. (2012). Impact of entrepreneurship education on entrepreneurial intentions of business and engineering students in Ethiopia. African Journal of Economic and Management Studies, 3(2), 258-277. doi:10.1108/20400701211265036.

Heinonen, J., \& Poikkijoki, S. (2006). An entrepreneurial-directed approach to entrepreneurship education: Mission impossible? Journal of Management Development, 25(1), 80-94. doi:10.1108/02621710610637981.

Hermawan, A., \& Pravitasari, R. J. (2010). Business Model Canvas. http://akselerasi. id/.

Hisrich, R. D., Peters, M. P., \& Shepherd, D. A. (2008). Entrepreneurship. Boston, MA: McGraw-Hill Irwin.

Hutasuhut, S. (2018). The roles of entrepreneurship knowledge, self- efficacy, family, education, and gender on entrepreneurial intention. Dinamika Pendidikan, 13(1), 90-105. doi:10.15294/ dp.v13i1.13785.

Indarti, N., \& Rostiani, R. (2008). Undergraduate student's entrepreneurial intention: A comparative study among Indonesia, Japan and Norway. Journal of Economics and Business Indonesia (Jurnal Ekonomika Dan Bisnis Indonesia), 23(4).

Ismail, M., Khalid, S. A., Othman, M., Jusoff, H. K., Rahman, N. A., Kassim, K. M., \& Zain, R. S. (2009). Entrepreneurial intention among Malaysian undergraduates. International Journal of Business and Management, 4(10), 54-60. doi:10.5539/ ijbm.v4n10p54.

Jakubczak, J., \& Rakowska, A. (2013, 19-21 June). The role of education and culture in the development of youth entrepreneurship in European Union. Paper presented at Management, Knowledge and Learning Internafional Conference, Zadar, Croatia. http://www.toknowpress.net/I.

Krueger, N. F., \& Carsrud, A. L. (1993). Entrepreneurial intentions: Applying the theory of planned behaviour. Entrepreneurship \& Regional Development, 5(4), 315-330

Kyro, P. (2003). Entrepreneurship pedagogythe current public and some future expectations. Paper presented at the $3^{\text {rd }}$ European Summer University, Paris, France.

Kusmintarti, A., Thoyib, A., Maskie, G., \& Ashar, K. (2016). Entrepreneurial characteristics as a mediation of entrepreneurial education influence on entrepreneurial intention. Journal of Entrepreneurship Education, 19(1), 24-37.

Küttim, M., Kallaste, M., Venesaar, U., \& Kiis, A. (2014). Entrepreneurship education at university level and students' entrepreneurial intentions. ProcediaSocial and Behavioral Sciences, 
110(2014), 658-668. doi:10.1016/j. sbspro.2013.12.910.

Lima, M., \& Baudier, P. (2017). Business model canvas acceptance among French entrepreneurship students: Principles for enhancing innovation artefacts in business education. Journal of Innovation Economics Management, (2), 159-183. doi:10.3917/jie.pr1.0008.

Liñán, F., \& Chen, Y. W. (2009). Development and cross-cultural application of a specific instrument to measure entrepreneurial intentions. Entrepreneurship: Theory and Practice, 33(3), 593-617. doi:10.1111/ j.1540-6520.2009.00318.x.

Liñán, F., Rodríguez-Cohard, J. C., \& RuedaCantuche, J. M. (2011). Factors affecting entrepreneurial intention levels: A role for education. International Entrepreneurship and Management Journal, 7(2), 195-218. doi:10.1007/s11365-010-0154-z.

Martin, B. C., McNally, J. J., \& Kay, M. J. (2013). Examining the formation of human capital in entrepreneurship: A meta-analysis of entrepreneurship education outcomes. Journal of Business Venturing, 28(2), 211224. doi:10.1016/j.jbusvent.2012.03.002.

Michael, J. (2006). Where's the evidence that active learning works? 30(4), 159-167. doi:10.1152/advan.00053.2006.

Mikic, M., Sopta, M., \& Horvatinovic, T. (2018). The role of entrepreneurial education in the development of entrepreneurship. Casopis Za Ekonomiju I Trzisne Komunikacije, 8(2), 385-395. doi:10.7251/EMC1802385M.

Murtini, W. (2008). Success story sebagai pendekatan pembelajaran kewirausahaan. [Success story as an entrepreneurial learning approach]. Varia Pendidikan, 20(2), 173-183.

Nowiński, W., Haddoud, M. Y., Lančarič, D., Egerová, D., \& Czeglédi, C. (2017). The impact of entrepreneurship education, entrepreneurial self-efficacy and gender on entrepreneurial intentions of university students in the Visegrad countries. Studies in Higher Education, 5079(August), 1-19. doi:10.1080/03075079.2017.1365359.

Nursito, S., Julianto, A., \& Nugroho, S. (2013). Analisis pengaruh interaksi pengetahuan kewirausahaan dan efikasi diri terhadap intensi kewirausahaan. [Analysis of the effect of the interaction of entrepreneurial knowledge and self-efficacy on entrepreneurial intentions]. Kiat Bisnis, 5(3), 201-211. http://journal.unwidha. ac.id/index.php/KIATBISNIS/article/ view/1042.

Osterwalder, A. (2004). The business model ontology a proposition in a design science approach (Doctoral dissertation, Université de Lausanne, Faculté des hautes études commerciales).

Osterwalder, A., \& Pigneur, Y. (2010). Business model generation: a handbook for visionaries, game changers, and challengers. John Wiley \& Sons.

Patricia, P., \& Silangen, C. (2016). The effect of entrepreneurship education on entrepreneurial intention in Indonesia. DeReMa Jurnal Manajemen, 11(1), 6786. doi:10.19166/derema.v11i1.184.

Premand, P., Brodmann, S.,Almeida, R., Grun, R., \& Barouni, M. (2016). Entrepreneurship education and entry into self-employment among university graduates. World Development, 77(C), 311-327. doi:10.1016/j.worlddev.2015.08.028.

Purwana, D., Suhud, U., \& Wibowo, S. F. (2018). Determinant factors of students' entrepreneurial intention: A comparative study. Dinamika Pendidikan, 13(1), 1-13. doi:10.15294/dp.v13i1.12971.

Rae, D. (2011). Entrepreneurial learning: A practical model fromthecreativeindustries. Education and Training, 46(8/9), 492500. doi:10.1108/00400910410569614. 
Raposo, M., \& Paço, A. (2011). Entrepreneurship education: Relationship between education. Psicothema, 23(3), 453-457. http://www.psicothema.com/.

Robles, L., \& Zárraga, M. (2015). Key competencies for entrepreneurship. Procedia Economics and Finance, 23(October 2014), 828-832. doi:10.1016/ S2212-5671(15)00389-5.

Roxas, B. G., Cayoka-, R. P., \& Jesus, R. M. de. (2008). Entrepreneurial knowledge and its effects on entrepreneurial intentions: Development of a conceptual framework. Asia-Pacifik Social Science Review, 8(2), 61-77. doi:10.3860/apssr.v8i2.784.

Roxas, B. (2014). Effects of entrepreneurial knowledge on entrepreneurial intentions: A longitudinal study of selected Southeast Asian business students. Journal of Education and Work, 27(4), 432-453. doi: 10.1080/13639080.2012.760191.

Sánchez, J. (2011). The influence of entrepreneurial competencies on small firm performance. Revista Latinoamericana de Psicología, 44(2), 165-177. http://www. scielo.org.co/.

Sirelkhatim, F., \& Gangi, Y. (2015). Entrepreneurship education: A systematic literature review of curricula contents and teaching methods. Cogent Business \& Management, 2(1), 1-11. doi:10.1080/233 11975.2015.1052034.

Solesvik, M. Z. (2019). Entrepreneurial competencies and intentions: The role of higher education. Forum Scientiae Oeconomia, 7(1), 9-23. doi:10.23762/ FSO_VOL7_NO1_1.
Solihah, E., Hubeis, A. V. S., \& Maulana, A. (2014). Analisis model bisnis pada KNM fish farm dengan pendekatan Business Model Canvas (BMC). [Analysis of business models on KNM fish farm with the Business Model Canvas (BMC) approach]. Jurnal Sosial Ekonomi Kelautan dan Perikanan, 9(2), 185-194. doi:10.15578/jsekp.v9i2.1220.

Suryana, Y., \& Bayu, K. (2010). Kewirausahaan: Pendekatan karakteristik wirausahawan sukses. [Entrepreneurship: A characteristic approach to successful entrepreneurs]. Jakarta: Kencana Predana Media Group.

Toro-Jarrín, M. A., Ponce-Jaramillo, I. E., \& Güemes-Castorena, D. (2016). Methodology for the of building process integration of Business Model Canvas and technological roadmap. Technological Forecasting and Social Change, 110(2016), 213-225. doi:10.1016/j. techfore.2016.01.009.

Türko, E. S. (2016). Business plan Vs Business Model Canvas in entrepreneurship trainings: A comparison of students' perceptions. Asian Social Science, 12(10), 55-62. doi:10.5539/ass.v12n10p55.

Westhead, P., Storey, D. J., \& Martin, F. (2001). Outcomes reported by students who participated in the 1994 Shell Technology Enterprise Programme. Entrepreneurship \& Regional Development, 13(2), 163-185. doi:10.1080/08985620010018273. 